\title{
Hemoglobin Subunit Alpha
}

National Cancer Institute

\section{Source}

National Cancer Institute. Hemoglobin Subunit Alpha. NCI Thesaurus. Code C75434.

Hemog lobin subunit alpha (142 aa, $\sim 15 \mathrm{kDa}$ ) is encoded by both the human HBA1 and human HBA2 genes. This protein plays a role in the distribution of oxygen from the lungs to other organs and tissues. 